\title{
Postweaning growth of the non-carcass components of Texel crossbred lambs
}

\section{Diego Barcelos Galvani ${ }^{1}$, Cleber Cassol Pires ${ }^{2}$, Tatiana Pfüller Wommer ${ }^{1}$, Franciele de Oliveira $^{3}$, Georges Petrarca Teixeira Kodayssi ${ }^{4}$, Letieri Griebler ${ }^{5}$}

1 Programa de Pós-graduação em Zootecnia, Universidade Federal de Santa Maria (UFSM), CEP: 97105-900, Santa Maria, RS, Brasil.

2 Departamento de Zootecnia, UFSM, Santa Maria, RS, Brasil.

3 Programa de Pós-graduação em Zootecnia, FMVZ/UNESP, Botucatu, SP, Brasil.

${ }^{4}$ Curso de Medicina Veterinária, UFSM, Santa Maria, RS, Brasil.

${ }^{5}$ Curso de Zootecnia, UFSM, Santa Maria, RS, Brasil.

ABSTRACT- Twenty 11/16 Texel $\times 5 / 16$ Ile de France crossbred lambs were slaughtered at different body weights to evaluate the growth of their non-carcass components. Animals were weaned at 42 days of age $(15.9 \pm 2.1 \mathrm{~kg}$ of body weight), housed in individual stalls, and fed ad libitum. After ten days of an experimental adaptation period, 5 lambs were slaughtered. The remaining lambs were randomly assigned to one of three following slaughter weights: 25,30 or $35 \mathrm{~kg}$ of body weight at fast. At slaughter, all body components were individually weighed and expressed as percentage of the empty body weight. To determine allometric growth of individual components, the exponential equation $\mathrm{Y}=\mathrm{a} \mathrm{X}^{\mathrm{b}}$ was logarithmically transformed and used. Proportions of feet and head decreased, while wool proportion increased linearly as slaughter weight increased. Greater fat deposition in viscera (kidney and mesenteric fat) was observed for lambs slaughtered at more elevated body weights. Growth rate of small intestine was lower than that of the empty body $(b=0.39)$, and it decreased linearly as a proportion of empty body weight with advancing maturity. Growth rates of both liver and large intestine were isogonics $(b=0.90$ and 1.08 , respectively), i.e., similar to the empty body weight. On the other hand, rumen presented late growth $(b=1.37)$, and its proportion was lower only for the lambs slaughtered at weaning (1.58\% of EBW). Once increased slaughter weights result in higher deposition of nutrients on body parts that are not intended to consumption, maximum slaughter weight of 11/16 Texel $\times 5 / 16$ Ile de France crossbred lambs is recommended to be at $30 \mathrm{~kg}$ of body weight.

Key Words: allometry, gastrointestinal tract, intestines, organs, sheep, viscera,

\section{Crescimento dos componentes não-integrantes da carcaça de cordeiros mestiços Texel no período pós-desmama}

RESUMO - Vinte cordeiros 11/16 Texel × 5/16 Ile de France foram abatidos em diferentes pesos com o objetivo de avaliar o crescimento dos componentes não-integrantes da carcaça. Os animais foram desmamados aos 42 dias de idade $(15,9 \pm 2,1$ $\mathrm{kg}$ de peso corporal) e confinados em baias individuais, recebendo alimentação à vontade. Após um período de 10 dias de adaptação às condições experimentais, 5 cordeiros foram abatidos e os remanescentes foram aleatoriamente sorteados para serem abatidos aos 25,30 ou $35 \mathrm{~kg}$ de peso corporal em jejum. Ao abate, cada componente corporal foi pesado individualmente, e seus valores expressos em percentual do peso de corpo vazio (PCV). Para determinação do crescimento alométrico de cada componente, foi utilizada a equação exponencial $Y=a X^{b}$, transformada logaritmicamente em um modelo linear. As proporções de patas e cabeça decresceram, e a de lã aumentou linearmente de acordo com o peso de abate. Observou-se acentuado acúmulo de gordura interna (renal e mesentérica) no corpo dos animais abatidos em pesos mais elevados. A taxa de crescimento do intestino delgado foi menor que a do corpo vazio $(b=0,39)$ o que reduziu a proporção desse órgão com o avanço da maturidade. O crescimento do fígado e do intestino grosso foi isogônico, ou seja, equivalente ao do corpo vazio (b $=0,90$ e 1,08 , respectivamente), enquanto o rúmen foi heterogônico e tardio $(b=1,37)$. Menores proporções de rumen foram observadas apenas para os animais abatidos logo após o desmame (1,58\%). Tendo em vista que pesos de abate mais elevados resultam em maior acúmulo de nutrientes em regiões do corpo não-destinadas ao consumo humano, recomenda-se que o abate de cordeiros 11/16 Texel $\times 5 / 16$ Ile de France seja realizado com, no máximo, $30 \mathrm{~kg}$ de peso vivo.

Palavras-chave: alometria, intestinos, órgãos, ovinos, trato gastrintestinal, vísceras

Received March 18, 2009 and accepted October 10, 2009

Corresponding author:dbg@mail.ufsm.br 


\section{Introduction}

Efficiency of nutrient use to improve production of food for human consumption has a great importance to maximize profitability of livestock production systems. Although this efficiency has been usually discussed as gain to feed ratio, as well as its relationship with nutritional requirements, particularly in meat production systems, it can be also represented by an increased carcass yield.

Proportions of different non-carcass components facing the empty body weight and also the proportion of gastrointestinal content are the main factors that affect carcass yield (Carvalho et al., 2007). Pires et al. (2000) showed that some organs can be proportionally greater at more advanced maturity, dropping the retention of tissues in the carcass. Therefore, a high feed efficiency cannot always represent a high efficiency of food production, and knowledge about growth rate from distinct body components can help to determine an adequate slaughter weight in which carcass yield will be maximized.

Moreover, some organs with high metabolic activity, like liver and gastrointestinal organs, demand a significant proportion of daily energy expenditure (Ferrell, 1988), and the study of their growth rate can contribute to improve the understanding on factors that affect nutritional requirements of the animals. Thus, the present study was conducted to evaluate the growth of non-carcass components of growing lambs, and to use these data to infer about a maximum adequate slaughter weight to Texel crossbred animals.

\section{Material and Methods}

This research was conducted from August 2006 to February 2007 at the Laboratório de Ovinocultura of the Universidade Federal de Santa Maria (UFSM), which is located in Santa Maria (2943'S; 5342'W, 95 m a.s.1.), RS, Brazil.

Twenty 11/16 Texel $\times 5 / 16$ Ile de France crossbred non castrated male lambs were weaned at 42 days of age $(15.9 \pm 2.1 \mathrm{~kg}$ of body weight; BW), treated for internal parasites, and placed in individual stalls $\left(1.5 \mathrm{~m}^{2}\right)$ equipped with feeders and a water source. Ten days after the beginning of experimental management and a diet adaptation period, five lambs were randomly chosen and slaughtered. The remaining 15 lambs were then assigned to one of the three slaughter groups, each one consisting of five randomly selected lambs that were fed ad libitum and slaughtered when they reached either 25,30 or $35 \mathrm{~kg}$ of shrunk body weight (SBW). The experimental diet (Table 1) consisted of
$55 \%$ sorghum silage (Sorghum bicolor (L.) Moench), $20.7 \%$ ground corn, $23.2 \%$ soybean meal, $0.85 \%$ calcium carbonate, and $0.25 \%$ salt (dry matter basis). Animals were fed twice, every day at 8:00 a.m. and 4:00 p.m., and the amount of feed offered was adjusted daily in the morning to assure a $10 \%$ refusalbased on the dry matter intake from the previous day.

At slaughter, lambs were fasted for 16 hours, electrically stunned, and sacrificed by exsanguination. Weights of the blood, viscera, skin, wool, head, feet, carcass, and adipose tissues removed from the internal organs were individually recorded. The digestive tract was weighed before and after emptying, and the gastrointestinal content was calculated as the difference between full and empty gastrointestinal tract (GIT) weight. Empty body weight (EBW) was then computed as the difference between shrunk body weight and the gastrointestinal tract content.

Data were analyzed in a completely randomized design by regression. Model included linear and quadratic effects of slaughter weight, using the obtained values as independent variables. To determine allometric growth of individual components, the exponential equation $\mathrm{Y}=\mathrm{a} \mathrm{X}^{\mathrm{b}} \mathrm{g}$, from Huxley (1932), was logarithmically transformed and used:

$$
\left.\log _{10} Y=\log _{10} a+b \log _{10} X+\varepsilon\right]
$$

where, $\mathrm{Y}=$ body component weight; $\mathrm{a}=$ the intercept of the linear regression; $b=$ the relative growth coefficient or allometric coefficient; $X=$ the empty body weight; and $\xi=$ the additive error. To verify if $b=1$ the $t$ Test was used; when $\mathrm{b}=1$, growth was denominated isogonics, indicating that growth rates of both $\mathrm{X}$ and $\mathrm{Y}$ were similar in the considered interval of empty body weight. On the other hand, when $b \neq 1$, growth was denominated heterogonic, being early if $b$ $<1$, and late if $\mathrm{b}>1$. Analyses were performed using SAS (2004) at a 5\% significance level.

Table 1 - Chemical composition of the experimental diet ${ }^{1}$

\begin{tabular}{lccc}
\hline Item & Silage & Concentrate & $\begin{array}{c}\text { Total } \\
\text { mixed diet }\end{array}$ \\
\hline $\begin{array}{l}\text { Dry matter (\%) } \\
\text { Composition }\end{array}$ & 34.6 & 80.8 & 46.6 \\
(\% of dry matter) & & & \\
Organic matter & 95.5 & 93.9 & 94.8 \\
Crude protein & 6.6 & 30.6 & 17.4 \\
Neutral detergent fiber & 47.4 & 9.9 & 30.6 \\
Acid detergent fiber & 24.8 & 3.7 & 15.3 \\
Lignin & 3.4 & 0.4 & 2.0 \\
Ether extract & 2.6 & 3.0 & 2.8 \\
Non-fibrous carbohydrate & 39.7 & 51.2 & 44.9 \\
\hline 1 Consisted of 55\% sorghum silage (Sorghum bicolor (L.) Moench), 20.7\% \\
ground corn, 23.2\% soybean meal, 0.85\% calcium carbonate, and 0.25\% salt \\
(dry matter basis).
\end{tabular}

R. Bras. Zootec., v.39, n.7, p.1558-1564, 2010 


\section{Results and Discussion}

Observed slaughter weights averaged 17.30, 25.24, 30.62 and $35.44 \mathrm{~kg}$ of SBW, and they corresponded to empty body weights of $15.15,20.61,20.74$ and $29.03 \mathrm{~kg}$, respectively. The relationship between empty body weight and shrunk body weight can be expressed by the following linear equation (Equation [1]; $\mathrm{r}^{2}=0.99$; root mean square error $=$ $0.55, \mathrm{n}=20)$ :

$\mathrm{EBW}, \mathrm{kg}=1.8603( \pm 0.51)+[0.7526( \pm 0.018) \times \mathrm{SBW}, \mathrm{kg}]$.

The shrunk body weight:empty body weight ratio, which indicates gastrointestinal tract content as a proportion of shrunk body weight, increased from 1.14 to lambs slaughtered at weaning, to 1.23 to animals slaughtered at more elevated body weights. Because the proportion of gastrointestinal tract content is directly related to the ruminal development, which is stimulated by the dry matter intake, mainly from fibrous foods (Baldwin et al., 2004), these results justify the highest carcass dressing percentages for lambs slaughtered immediately after weaning (Pérez et al., 2007; Santos et al., 2007).

Skin proportion (\% of empty body weight) was quadratically related $(\mathrm{P}<0.01)$ to the shrunk body weight, being highest at weaning and at $35 \mathrm{~kg}$ of shrunk body weight as well (Table 2). Pires et al. (2000) also observed higher proportions of skin in newborn lambs. Thus, our results suggest that skin has an important function in thermal insulation, and when combined to different physiological mechanisms (Piccione et al., 2007) it determines the capacity of adaptation to the environment and the homeothermy maintenance of lambs at initial development. On the other hand, increased skin proportion after $30 \mathrm{~kg}$ of shrunk body weight likely is related to an increased deposition of hypodermic fat, and it also was found by
Pires et al. (2000). Li et al. (2006) observed that skin thickness was positively correlated to the food intake, once it affects the rate of fat deposition, suggesting that differences in sheep skin weight can be attributed to dermis thickness.

Proportions of feet and head decreased $(\mathrm{P}<0.01)$ while wool proportion increased linearly $(\mathrm{P}<0.001)$ as slaughter weight increased (Table 2). Head and feet are proportionally greater at less mature animals (Aziz et al., 1993; Pires et al., 2000) because of the tissue composition of these body parts. According to Rosa et al. (2005), bone growth occurs at an early stage of development and, therefore, younger animals present greater proportions of this tissue. Since a large part of feet and head weights are represented by osseous tissue, those parts of the body are also more representative at lower body weights.

The increased proportion of wool observed on animals during their growing can be explained by the day-length during the experimental period (from August to December). Bigham et al. (1978) suggested that in meat purpose breeds, wool growth rate in the summer is two to three times greater than in winter. Thus, increasing day-length during the experimental period might have resulted in a greater rate of wool growth and, consequently, in an increased proportion of wool in relation to the empty body weight.

There was a reduction in the proportions of the kidney and lung $(\mathrm{P}<0.01)$ while reproductive tract proportionally enlarged $(\mathrm{P}<0.001)$ as body weight increased (Table 3$)$. Piccione et al. (2007) stated that during the first 4 weeks post-partum, the respiratory activity of lambs presents an irregular pattern, which is characterized by the alternation of apnea, bradycardia, eupnea, and tachycardia (Hilaire \& Duron, 1999). Our results suggest, therefore, that this may be partially compensated by an increased pulmonary volume in newborn lambs. The greater proportion of kidney at weaning may be a consequence of its function during intrauterine life. Fetal kidneys provide fluid and electrolytes

Table 2 - Shrunk and empty body weight, and proportions (\% of EBW) of non-visceral body components of Texel $\times$ Ile de France crossbred lambs

\begin{tabular}{|c|c|c|c|c|c|c|c|c|}
\hline \multirow[b]{2}{*}{ Component } & \multicolumn{4}{|c|}{ Slaughter group } & \multirow[b]{2}{*}{ SEM } & \multirow[b]{2}{*}{$\mathrm{r}^{2}$} & \multicolumn{2}{|c|}{ P-value ${ }^{1}$} \\
\hline & $\begin{array}{c}10 \text { days } \\
\text { after } \\
\text { weaning }\end{array}$ & $\begin{array}{c}25 \mathrm{~kg} \\
\text { of } \\
\text { SBW }\end{array}$ & $\begin{array}{c}30 \mathrm{~kg} \\
\text { of } \\
\text { SBW }\end{array}$ & $\begin{array}{c}35 \mathrm{~kg} \\
\text { of } \\
\text { SBW }\end{array}$ & & & $\mathrm{L}$ & Q \\
\hline Shrunk body weight (kg) & 17.30 & 25.54 & 30.62 & 35.44 & 0.168 & - & - & - \\
\hline Empty body weight (kg) & 15.15 & 20.61 & 24.74 & 29.03 & 0.146 & - & - & - \\
\hline Skin & 10.94 & 9.18 & 8.38 & 9.59 & 0.151 & 0.72 & $\mathrm{~ns}$ & $* *$ \\
\hline Blood & 4.98 & 5.25 & 5.03 & 5.34 & 0.091 & 0.06 & $\mathrm{~ns}$ & ns \\
\hline Feet & 3.33 & 2.99 & 2.75 & 2.74 & 0.040 & 0.67 & $* * *$ & $\mathrm{~ns}$ \\
\hline Head & 4.55 & 4.56 & 4.21 & 4.02 & 0.043 & 0.51 & $* *$ & $\mathrm{~ns}$ \\
\hline
\end{tabular}

$\mathrm{SBW}=$ shrunk body weight SEM $=$ Standard error of the mean

${ }^{1}$ Probability of either linear $(\mathrm{L})$ or quadratic $(\mathrm{Q})$ effect of increasing slaughter weight, where: $\mathrm{ns}=$ non significant, $* * \mathrm{P}<0.01$ and $* * * \mathrm{P}<0.001$. 
into the amniotic cavity, maintaining the amniotic fluid volume. The lack of sufficient amniotic fluid impairs the development of the fetal lung, limb, and gut, sometimes to the point in which life after birth is not possible (Lumbers, 1995). Concerning the reproductive tract, the observed result is a consequence of advancing sexual maturity.

It was not found $(\mathrm{P}>0.05)$ effects of slaughter weight on the proportions of tongue, heart, and spleen, and they averaged $0.53,0.65$, and $0.19 \%$ of empty body weight, respectively (Table 3 ). On the other hand, kidney fat, which can be used as an indicative of fat deposition in the carcass (Osório et al., 1998), increased linearly $(\mathrm{P}<0.001)$ as body weight increased, as it was also observed for fat associated to the gastrointestinal tract (Table 4). Silva et al. (2003) showed a positive correlation $(r=0.48)$ between kidney plus mesenteric fat and the subcutaneous fat thickness. However, according to Kempster (1981), kidney fat deposition is late when it is compared to carcass fat accretion. Thus, higher proportions of kidney and gastrointestinal tract fat observed in our study to lambs slaughtered at 35 $\mathrm{kg}$ of shrunk body weight may indicate an excessive fat deposition on carcass at that weight, which can be undesirable as a "business characterization". Moreover, a greater accumulation of visceral fat determines a proportional reduction in carcass yield, consequently a worse conversion of ingested nutrients to edible tissues. Similar results were obtained by Pires et al. (2000) and Barone et al. (2007).

Concerning to the gastrointestinal organs (Table 4), a linear effect $(\mathrm{P}<0.001)$ of shrunk body weight on the proportion of omasum was observed while proportions of rumen $(\mathrm{P}<0.01)$ and reticulum varied quadratically, being greater to lambs slaughtered immediately after weaning. Proportion of abomasum decreased linearly $(\mathrm{P}<0.05)$ as shrunk body weight increased. As previously discussed, development of rumen-reticulum is directly related to feed intake (Baldwin et al., 2004). Zupka et al. (1996) described that rumen, reticulum, and omasum increase up to an intermediate stage of development, when milk fed is interrupted and a solid diet is given to lambs. This fact still results in a decreasing proportion of abomasum and small intestine as well, as it was observed in our study.

These results have a great importance under the nutritional aspect because of the elevated metabolic rate of some visceral organs (Ferrell, 1988). Although protein content of visceral tissues (GIT plus liver) accounts for only 7 to $8 \%$ of whole-body protein (Lobley et al., 1980), it contributes up to $50 \%$ of daily whole-body protein turnover (Attaix et al., 2005), demanding a significant proportion of daily energy requirements for maintenance (Ferrell \& Jenkins, 1998). Thus, Blaxter (1962) suggested that energy requirements for maintenance of sheep decreases linearly from the birth to the sixth year of age (average age at slaughter were 52, 87, 106, and 117 days for lambs slaughtered at slaughter, 25,30 , or $35 \mathrm{~kg}$ of shrunk body weight, respectively), which can be related to increasing body fat content, but mainly to the decreasing rate of body protein turnover (Attaix et al., 2005). However, our results still suggest that those variations in maintenance requirements may be related with the linear decrease in the size of small intestine, which ranged from 50 to $36 \%$ of the total gastrointestinal tract weight for lambs slaughtered either at weaning or at $35 \mathrm{~kg}$ of SBW, respectively. In our study, proportion of liver was not affected by the slaughter weight, and it averaged $1.85 \%$ of EBW, similarly to results obtained by Pires et al. (2000), Carvalho et al. (2005), and Santos-Cruz et al. (2009).

The results found in this study can be also analyzed by using allometric equations of each body component, as a function of empty body weight (Table 5). In the studied

Table 3 - Average proportions (\% of EBW) of red internal organs, kidney fat, and reproductive tract of Texel $\times$ Ile de France crossbred lambs

\begin{tabular}{|c|c|c|c|c|c|c|c|c|}
\hline \multirow[b]{2}{*}{ Component } & \multicolumn{4}{|c|}{ Slaughter group } & \multirow[b]{2}{*}{ SEM } & \multirow[b]{2}{*}{$r^{2}$} & \multicolumn{2}{|c|}{ P-value ${ }^{1}$} \\
\hline & $\begin{array}{c}10 \text { days } \\
\text { after } \\
\text { weaning }\end{array}$ & $\begin{array}{l}25 \mathrm{~kg} \\
\text { of } \\
\text { SBW }\end{array}$ & $\begin{array}{c}30 \mathrm{~kg} \\
\text { of } \\
\text { SBW }\end{array}$ & $\begin{array}{c}35 \mathrm{~kg} \\
\text { of } \\
\text { SBW }\end{array}$ & & & $\mathrm{L}$ & Q \\
\hline Tongue & 0.57 & 0.54 & 0.49 & 0.50 & 0.014 & 0.16 & ns & ns \\
\hline Heart & 0.73 & 0.72 & 0.65 & 0.49 & 0.013 & 0.14 & $\mathrm{~ns}$ & $\mathrm{~ns}$ \\
\hline Liver & 1.87 & 1.96 & 1.69 & 1.83 & 0.028 & 0.06 & ns & ns \\
\hline Kidney & 0.39 & 0.37 & 0.30 & 0.33 & 0.006 & 0.46 & $* *$ & $\mathrm{~ns}$ \\
\hline Kidney fat & 0.26 & 0.31 & 0.38 & 0.57 & 0.019 & 0.57 & $* * *$ & $\mathrm{~ns}$ \\
\hline Spleen & 0.20 & 0.22 & 0.18 & 0.17 & 0.006 & 0.29 & ns & $\mathrm{ns}$ \\
\hline Lung + trachea & 2.05 & 1.85 & 1.65 & 1.72 & 0.046 & 0.33 & $* *$ & ns \\
\hline Reproductive tract & 0.51 & 0.71 & 0.91 & 0.97 & 0.022 & 0.80 & $* * *$ & $\mathrm{~ns}$ \\
\hline
\end{tabular}

SBW = shrunk body weight; EBW = empty body weight; SEM = standard error of the mean.

${ }^{1}$ Probability of either linear $(\mathrm{L})$ or quadratic $(\mathrm{Q})$ effect of increasing slaughter weight, where: $\mathrm{ns}=$ non significant, $* * \mathrm{P}<0.01$ and $* * * \mathrm{P}<0.001$. 
Table 4 - Average proportions (\% of EBW) of gastrointestinal organs and fat associated to the gastrointestinal tract of Texel $\times$ Ile de France crossbred lambs

\begin{tabular}{|c|c|c|c|c|c|c|c|c|}
\hline \multirow[b]{2}{*}{ Component } & \multicolumn{4}{|c|}{ Slaughter group } & \multirow[b]{2}{*}{ SEM } & \multirow[b]{2}{*}{$r^{2}$} & \multicolumn{2}{|c|}{ P-value ${ }^{1}$} \\
\hline & $\begin{array}{c}10 \text { days } \\
\text { after } \\
\text { weaning }\end{array}$ & $\begin{array}{c}25 \mathrm{~kg} \\
\text { of } \\
\text { SBW }\end{array}$ & $\begin{array}{c}30 \mathrm{~kg} \\
\text { of } \\
\text { SBW }\end{array}$ & $\begin{array}{c}35 \mathrm{~kg} \\
\text { of } \\
\text { SBW }\end{array}$ & & & $\mathrm{L}$ & Q \\
\hline Rumen & 1.58 & 2.13 & 2.00 & 2.04 & 0.034 & 0.68 & ns & $* * *$ \\
\hline Reticulum & 0.27 & 0.35 & 0.32 & 0.30 & 0.009 & 0.31 & ns & $*$ \\
\hline Omasum & 0.17 & 0.20 & 0.23 & 0.25 & 0.008 & 0.40 & $* * *$ & $\mathrm{~ns}$ \\
\hline Small intestine & 3.94 & 3.43 & 3.05 & 2.61 & 0.084 & 0.66 & $* * *$ & $\mathrm{~ns}$ \\
\hline Large intestine & 1.33 & 1.56 & 1.34 & 1.48 & 0.040 & 0.04 & $\mathrm{~ns}$ & $\mathrm{~ns}$ \\
\hline Gastrointestinal fat & 1.32 & 1.70 & 1.56 & 1.98 & 0.057 & 0.40 & $* * *$ & ns \\
\hline
\end{tabular}

SBW = shrunk body weight; EBW = empty body weight; SEM = standard error of the mean.

${ }^{1}$ Probability of either linear $(\mathrm{L})$ or quadratic $(\mathrm{Q})$ effect of increasing slaughter weight, where: $\mathrm{ns}=$ non significant, $* * \mathrm{P}<0.01$ and $* * * \mathrm{P}<0.001$.

interval of body weight, an early growth $(b<1)$ of skin, feet, head, kidney, lung, abomasum, and small intestine was observed. On the other hand, heart, liver, spleen, reticulum, and large intestine presented isogonics growth $(b=1)$, while growth of wool, omasum, rumen, reproductive tract, kidney fat, and fat associated to GIT was late (b>1), indicating that their proportions increased at more elevated empty body weights, as previously discussed. Allometric coefficients found in this study are similar to those observed by Pires et al. (2000). However, those authors reported an early growth of heart $(b=0.61)$, likely due the interval of body weight in which lambs were slaughtered (4 to $33 \mathrm{~kg}$ of BW).

These results may be used to establish an adequate slaughter weight, in which the efficiency of meat production would be maximized. However, to do this based only on the allometric equations can be not easy because there is no published information concerning a maximum or optimal proportion of any organ or visceral fat depot. On the other hand, it is possible to make some relationship between kidney and carcass fat, and then use it to infer about a theoretical optimal slaughter weight.

Using data of carcass tissue composition (previously published by Galvani et al., 2008) the allometric coefficient observed for the kidney fat $(b=2.13)$ was higher than that obtained for the carcass fat $(b=1.88)$ in a relation with the EBW. To better illustrate this point, we have related fat depots $\times$ total body fat. In fact, allometric growth of kidney fat was late $(b=1.26 ; \mathrm{P}<0.01)$ in relation to total body fat, while allometric growth of carcass fat was isogonics $(b=1.04)$. These findings are in agreement with Kempster (1981), who stated that deposition of kidney fat

Table 5 - Estimated parameters for the allometric equations of distinct body components

\begin{tabular}{|c|c|c|c|c|c|}
\hline Component & A & $\mathrm{b}$ & $\operatorname{se}^{\dagger}$ & $r^{2}$ & $\mathrm{t}(\mathrm{Ho}: \mathrm{b}=1)$ \\
\hline Skin & 0.2215 & 0.7237 & 0.0876 & 0.79 & $-3.1541 * *$ \\
\hline Wool & 0.0035 & 1.6954 & 0.1524 & 0.87 & $4.5630 * *$ \\
\hline Blood & 0.0427 & 1.0599 & 0.0705 & 0.93 & $0.8496^{\mathrm{ns}}$ \\
\hline Feet & 0.0812 & 0.6699 & 0.0478 & 0.92 & $-6.9059 * *$ \\
\hline Head & 0.0813 & 0.7947 & 0.0451 & 0.95 & $-4.5521 * *$ \\
\hline Tongue & 0.0023 & 0.9161 & 0.1112 & 0.79 & $-0.7545^{\mathrm{ns}}$ \\
\hline Heart & 0.0106 & 0.8608 & 0.0728 & 0.89 & $-1.9121^{\mathrm{ns}}$ \\
\hline Liver & 0.0249 & 0.9001 & 0.0741 & 0.89 & $-1.3482^{\mathrm{ns}}$ \\
\hline Kidney & 0.0101 & 0.6542 & 0.0839 & 0.77 & $-4.1216 * *$ \\
\hline Kidney fat & 0.0001 & 2.1284 & 0.2170 & 0.84 & $5.2000 * *$ \\
\hline Spleen & 0.0043 & 0.7360 & 0.1512 & 0.57 & $-1.7460^{\mathrm{ns}}$ \\
\hline Lung & 0.0479 & 0.6828 & 0.1051 & 0.70 & $-3.0181 * *$ \\
\hline Reproductive tract & 0.0003 & 2.0636 & 0.1159 & 0.95 & $9.1769 * *$ \\
\hline Rumen & 0.0062 & 1.3662 & 0.0955 & 0.92 & $3.8346 * *$ \\
\hline Reticulum & 0.0021 & 1.1317 & 0.1304 & 0.81 & $1.0100^{\mathrm{ns}}$ \\
\hline Omasum & 0.0004 & 1.5081 & 0.1619 & 0.83 & $3.1384 * *$ \\
\hline Abomasum & 0.0229 & 0.5355 & 0.1363 & 0.48 & $-3.4079 * *$ \\
\hline Small intestine & 0.2122 & 0.3861 & 0.0895 & 0.51 & $-6.8592 * *$ \\
\hline Large intestine & 0.0110 & 1.0821 & 0.1102 & 0.84 & $0.7450^{\mathrm{ns}}$ \\
\hline Gastrointestinal fat & 0.0037 & 1.4772 & 0.1447 & 0.85 & $3.2979 * *$ \\
\hline
\end{tabular}

$\dagger$ se $=$ Standard error of the regression coefficient

$\mathrm{ns}=$ Non significant, and $* * \mathrm{P}<0.01$. 
is late, when it is compared to fat deposited in the carcass, and they suggest that carcass fat deposition may be excessive at $35 \mathrm{~kg}$ of SBW.

The relationship found between kidney and carcass fat (Galvani et al., 2008), as a proportion of carcass weight, can be explained by the following equation (Equation [2]; $\mathrm{r}^{2}=0.84$; root mean square error $=22.26$; $\mathrm{n}=20 ; \mathrm{P}<0.001)$ :

kidney fat, $\mathrm{g}=-101.12( \pm 22.01)+[11.89( \pm 1.31) \times$ carcass fat, \%].

According to this equation and considering $16 \%$ as the maximum value of carcass fat proportion (Siqueira et al., 2001), the estimated kidney fat deposition was $89 \mathrm{~g}$, which is reached when the empty body weight is equal to $24.3 \mathrm{~kg}$, i.e., when the shrunk body weight is $29.8 \mathrm{~kg}$ (Equation 1). Therefore, we can infer that an adequate slaughter weight to $11 / 16$ Texel $\times 5 / 16$ Ile de France crossbred lambs is quite near to $30 \mathrm{~kg}$ of shrunk body weight.

\section{Conclusions}

Different body components present distinct growth patterns; feet, head, kidney, lung, abomasum, and small intestine are, proportionally, greater in more young Texel $\times$ Ile de France crossbred animals. Ruminal growth is directly related to the intake of solid food.Greaterbody weights at slaughter result in greater accumulation of kidney and mesenteric fat, reducing the conversion of ingested nutrients to products intended to human consumption. Therefore, it is recommended $30 \mathrm{~kg}$ as the maximum slaughter weight for $11 / 16$ Texel $\times 5 / 16$ Ile de France crossbred lambs.

\section{Acknowledgements}

The authors are thankful to Coordenação de Aperfeiçoamento de Pessoal de Ensino Superior (CAPES) for providing scholarship to Diego Barcelos Galvani and Tatiana Pfüller Wommer. Cleber Cassol Pires is a scientific researcher of Conselho Nacional de Desenvolvimento Científico e Tecnológico (CNPq).

\section{References}

ATTAIX, D.; RÉMOND, D.; SAVARY-AUZELOUX, I.C. Protein metabolism and turnover. In: DIJKSTRA, J.; FORBES, J.M.; FRANCE, J. (Eds.). Quantitative aspects of ruminant digestion and metabolism. 2.ed. Wallingford: $C A B$ International, 2005. p.373-397.
AZIZ, N.N.; MURRAY, D.M.; BALL, R.O. The effect of live weight gain and live weight loss on body composition of merino wethers: noncarcass organs. Journal of Animal Science, v.71, n.2, p.400-407, 1993.

BALDWIN, R.L.V.; MCLEOD, K.R.; KLOTZ, J.L. et al. Rumen development, intestinal growth and hepatic metabolism in the pre- and postweaning ruminant. Journal of Dairy Science, v. 87, n.13, p.55-65, 2004 (suppl.)

BARONE, C.M.A.; COlATRUGlio, P.; GIROLAMI, A. et al. Genetic type, sex, age at slaughter and feeding system effects on carcass and cut composition in lambs. Livestock Science, v.112, n.1-2, p.133-142, 2007.

BIGHAM, M.L.; SUMNER, R.M.W.; ELLIOTT, K.H. Seasonal wool production of Romney, Coopworth, Perendale, Cheviot and Corriedale wethers. New Zealand Journal of Agricultural Research, v.21, n.2, p.377-382, 1978.

BLAXTER, K.L. The fasting metabolism of adult wether sheep. British Journal of Nutrition, v.16, n.1, p.615-626, 1962.

CARVALHO, S.; VERGUEIRO, A.; KIELING, R. et al. Avaliação da suplementação concentrada em pastagem de Tifton-85 sobre os componentes não carcaça de cordeiros. Ciência Rural, v.35, n.2, p.435-439, 2005.

CARVALHO, S.; BROCHIER, M.A.; PIVATO, J. et al. Desempenho e avaliação econômica da alimentação de cordeiros confinados com dietas contendo diferentes relações volumoso:concentrado. Ciência Rural, v.37, n.5, p.1411-1417, 2007.

FERRELL, C.L. Contribution of visceral organs to animal energy expenditures. Journal of Animal Science, v.66, n.3, p.23-24, 1988. (Suppl.)

FERRELL, C.L.; JENKINS, T.G. Body composition and energy utilization by steers of diverse genotypes fed a high-concentrate diet during the finishing period: II. Angus, Boran, Brahman, Hereford, and Tuli sires. Journal of Animal Science, v.76, n.2, p.647-657, 1998.

GALVANI, D.B.; PIRES, C.C.; OLIVEIRA, F.D. et al. Crescimento alométrico dos componentes da carcaça de cordeiros texel $\mathrm{x}$ ile de france confinados do desmame aos $35 \mathrm{~kg}$ de peso vivo. Ciência Rural, v.38, n.9, p.2574-2578, 2008.

HILAIRE, G.; DURON, B. Maturation of the mammalian respiratory system. Physiological Reviews, v.79, n.2, p.325-360, 1999.

HUXLEY, J.S. Problems of relative growth. London: Methuen, 1932. 276p.

KEMPSTER, A.J. Fat partition and distribution in the carcasses of cattle, sheep and pigs: A review. Meat Science, v.5, n.2, p.83-98, 1981

LI, L.; GODWIN, I.; LIU, S.M. et al. Skin characteristics and skin protein composition of Merinos differing in estimated breeding values for wool growth and fed at above and below maintenance. Australian Journal of Experimental Agriculture, v.46, n.7, p.937-941, 2006.

LOBLEY, G.E.; MILNE, V.; LOVIE, J.M. et al. Whole body and tissue protein synthesis in cattle. British Journal of Nutrition, v.43, n.3, p.491-502, 1980.

LUMBERS, E.R. Development of renal-function in the fetus - a review. Reprodu ction Fertility and Development, v.7, n.3, p.415-426, 1995.

OSÓRIO, J.C.S.; OSÓRIO, M.T.M.; JARDIM, P.O. et al. Métodos para avaliação da produção de carne ovina: in vivo, na carcaça e na carne. Pelotas: UFPEL, 1998. 98p.

PÉREZ, P.; MAINO, M.; MORALES, M.S. et al. Gender and slaughter weight effects on carcass quality traits of suckling lambs from four different genotypes. Small Ruminant Research, v.70, n.2, p.124-130, 2007.

PICCIONE, G.; BORRUSO, M.; FAZIO, F. et al. Physiological parameters in lambs during the first 30 days postpartum. Small Ruminant Research, v.72, n.1, p.57-60, 2007.

PIRES, C.C.; SILVA, L.F.; FARINATTI, L.H.E. et al. Crescimento de cordeiros abatidos com diferentes pesos. 2. Constituintes corporais. Ciência Rural, v.30, n.5, p.869-873, 2000. 
ROSA, G.T.; PIRES, C.C.; SILVA, J.H.S. et al. Crescimento alométrico de osso, músculo e gordura em cortes da carcaça de cordeiros Texel segundo os métodos de alimentação e peso de abate. Ciência Rural, v.35, n.4, p.870-876, 2005.

SANTOS, V.A.C.; SILVA, S.R.; MENA, E.G. et al. Live weight and sex effects on carcass and meat quality of "Borrego terrinchoPDO” suckling lambs. Meat Science, v.77, n.4, p.654-661, 2007.

SANTOS-CRUZ, C.L.; PEREZ, J.R.O.; MUNIZ, J.A. et al. Desenvolvimento dos componentes do peso vivo de cordeiros Santa Inês e Bergamácia abatidos em diferentes pesos. Revista Brasileira de Zootecnia, v.38, n.5, p.923-932, 2009.

SIQUEIRA, E.R.; SIMÕES, C.D.; FERNANDES, S. Efeito do sexo e do peso ao abate sobre a produção de carne de cordeiro. Morfometria da carcaça, pesos dos cortes, composição tecidual e componentes não constituintes da carcaça. Revista Brasileira de Zootecnia, v.30, n.4, p.1299-1307, 2001.

SILVA, L.F.; PIRES, C.C.; SILVA, J.H.S. et al. Crescimento de cordeiros abatidos com diferentes pesos. 1. Osso, músculo e gordura da carcaça e de seus cortes. Ciência Rural, v.30, n.4, p.671-675, 2000.

SILVA, S.L.; LEME, P.R.; PEREIRA, A.S.C. et al. Correlações entre características de carcaça avaliadas por ultra-som e pós-abate em novilhos Nelore, alimentados com altas proporções de concentrado. Revista Brasileira de Zootecnia, v.32, n.5, p.1236-1242, 2003.

STATISTICAL ANALYSES SYSTEM - SAS. SAS/STAT ${ }^{8} 9.1$ User's guide. Cary: SAS Institute Inc., 2004. 5135p.

ZUPKA, Z.; JELÍNEK, P.; SUBRT, J. Allometric analysis of ram growth in the postnatal period. Zivocisna Vyroba, v.41, n.9, p.387-390, 1996. 